\title{
INTEGRATING TRUST INTO TECHNOLOGY ACCEPTANCE MODEL (TAM), THE CONCEPTUAL FRAMEWORK FOR E-PAYMENT PLATFORM ACCEPTANCE
}

\section{Dickson Ben Uche1, Oby Blessing Osuagwu², Samuel Ngozichikanma Nwosu ${ }^{3}$ and Udoka Stephen Otika ${ }^{4}$}

${ }^{1}$ Department of Marketing, Evangel University, Akaeze, Ebonyi State Email:profuvc@gmail.com

\author{
${ }^{2}$ Department of Business Administration, Hezekiah University, Umudi, Imo State, Nigeria \\ Email: rhina.201@gmail.com \\ ${ }^{3}$ Department of Accounting, Evangel University, Akaeze, Ebonyi State \\ Email: $\underline{\text { samca880@gmail.com }}$ \\ ${ }^{4}$ Department of Marketing, Evangel University, Akaeze, Ebonyi State \\ Email: ud.otika@evangeluniversity.edu.ng, otikaudoka3gmail.com
}

Cite this article:

Dickson B.U., Oby B.O., Samuel N.N., Udoka S.O. (2021), Integrating Trust into Technology Acceptance Model (TAM), the Conceptual Framework for E-Payment Platform Acceptance. British Journal of Management and Marketing Studies 4(4), 34-56. DOI: $10.52589 / \mathrm{BJMMS}-$ TB3XTKPI.

\section{Manuscript History \\ Received: 8 Sep 2021 \\ Accepted: 22 Sept 2021 \\ Published: 25 Nov 2021}

Copyright $\odot 2020$ The Author(s). This is an Open Access article distributed under the terms of Creative Commons AttributionNonCommercial-NoDerivatives 4.0 International (CC BY-NC-ND 4.0), which permits anyone to share, use, reproduce and redistribute in any medium, provided the original author and source are credited.

\begin{abstract}
Innovations acceptance is attracting increasing attention. Researchers are particularly interested in factors that affect the adoption of IS and IT innovations. However, despite numerous advantages of e-payment usage such as convenience, speed, efficiency and reduced cost, the economic ecosystem is skeptical to embrace e-payment systems (Adeyelure, Pretorius \& Kalema, 2014). This research develops extended TAM model by integrating the three dimensions of trust (integrity, benevolence aOnd competence) and two key constructs from technology acceptance models (perceived ease of use and perceived usefulness of e-payment) to explain online consumers' intentions to engage in the business relationship with e-payment. Through this framework, researchers can have a more accurate explanation of the consumer behavior and intention to accept new technology. This framework will be used to examine consumer's behavioral intention to accept e-payment by researchers.
\end{abstract}

KEYWORDS: Trust, Integrity, Benevolence, Ability, TAM Model, Attitude, Intention. 


\section{INTRODUCTION}

Trust is one of the cardinal elements of the digital economy, and a lubricant that makes efficient markets possible. Without trust, few transactions would take place. While mutual benefit is often the reason behind a transaction, trust is the insurance or likelihood that the purchaser will receive that benefit. While trust is important for all types of business, trust is even more crucial in the online business environment. Quelch and Klein (1996) showed that trust is a key factor in stimulating Internet purchases, especially at the early stages of commercial development.

An identifiable stream of research therefore integrates trust with key constructs from wellknown technology acceptance models, such as the TAM (Davis, Bagozzi and Warshaw, 1989) or the more recent UTAUT model (Venkatesh et al., 2003). However, a more elaborate understanding of how trust and technological acceptance drive behavior may be gained when trust is decomposed into its dimensions (McKnight, Choudhury and Kacmar, 2002). We decompose trust into its three dimensions (integrity, benevolence and ability) and explore how these dimensions interact with the two key constructs of technology acceptance model to ultimately explain consumers' intentions to engage into a business relationship with the epayment.

Embracing innovative technologies especially in financial services has become a major focus of research scholars in recent times (Venkatesh, Morris, Davis \& Davis, 2003). Many of the studies are directed towards factors that influence user's decision to adapt innovation (Teo, Wei, \& Benbasat, 2003; Venkatesh \& Brown, 2001). Numerous studies have reported on how potential users' perceptions of the innovative technologies influence their acceptance or usage (Lewis, Agarwal, \& Sambamurthy, 2003; Moore \& Benbasat, 1991). Substantial theoretical and empirical progress has been made in explaining and predicting user acceptance of IT. In particular, the Technology Acceptance Model (TAM) has become well-established as a model for predicting IT acceptance, usage intentions and behavior via the mediating variables perceived usefulness and perceived ease of use (Davis 1989, Davis, Bagozzi and Warshaw, 1989). In line with a large body of research that extended the TAM (King and He, 2006; Venkatesh \& al., 2003), the goal of the present research is to enrich the TAM by integrating trust construct which is permissible by original TAM model.

Several techniques of e-payments are currently altering the manner businesses are carried out over the Internet, including e-banking, e-ordering and online publishing/online retailing (Okoro \& Kigho, 2013), by permitting the exchange of finances and information rapidly, easily, and reliably than before. The benefits of e-payments cannot be overemphasized, ranging from cost reduction, flexibility, convenience, enhanced productivity and efficiency, tracking individual spending, and it has changed the financial ecosystem from brick and muter system to electronic payment system. However, notwithstanding its advantages, consumers in developing countries are not eager to disclose sensitive financial data over the web; the unwillingness to provide sensitive personal data for instance credit card numbers to transact businesses over the internet is still strong in developing countries (Lawrence \& Tar, 2010). Despite numerous advantages of e-payment usage such as convenience, speed, efficiency and reduced cost, consumers are skeptical to embrace e-payment systems (Adeyelure, Pretorius \& Kalema, 2014). This is occasioned by some vital problems such as; inability to trust the system, cybercrime, internet frauds and perceived lack of security with e-payment still discourage the escalation of etransaction (Adeshina \& Ayo, 2010). Because of lack of trust on the part of consumers, Internet transactions have witnessed stunted growth, due to the fear of consumers committing their 
money on an untrusted system (Akintola et al (2011). Arguably, the extant literatures have not fully addressed or further understand from user perspective why they feel skeptical about electronic payment platforms. The essence of the current study is to develop a framework that will incorporate trust in e-payment acceptance with a theoretical base from the TAM model developed by Davis, (1989). The developed model will provide confidence to e-payment patronage and also contribute to financial inclusion in the financial ecosystem.

\section{REVIEW OF RELATED LITERATURES}

\section{E-payment Platform}

Electronic payment is relatively a novel phenomenon (Abubakar \& Adebayo, 2014). Epayments in the context of e-commerce are seen as online transactions that are conducted by the use of the Internet (Armesh, and Hamed 2010). According to Tella and Adeyinka (2012) epayments is defined as the process of payment made devoid of the application of paper instruments. The e-payment platform comprises online credit card transaction, electronic wallet (e-wallet), electronic cash (e-cash), online stored value systems, digital accumulating balance systems, digital checking payment systems and wireless payment systems. (Laudon, Kenneth, Traver, and Carol, 2011). The basic concept of e-payment is a payment transaction by means of the internet through a distinctive token that has been confirmed to represent money from the consumer to the merchant. In developing countries, cash transactions have been the major mode of payment. Arguably, a payment system that operates less on cash is an avenue for financial inclusion, national development and a major national infrastructure for growth, (Osazevbaru \& Yomere, 2015). Furthermore, in the long run the usage of e-payment systems is anchored on the consumer's behaviour, (Adeyelure et al, 2014). Gholami et al. (2010) in his study establish that customer trust affects individuals' intention to adopt electronic payments. Adeshina and Ayo (2010) observed that there is evident low-level of trust in the security measures of internet banking technology and the competence of internet banking systems to protect privacy. Customers' trust in an Internet environment is very essential as there is slight assurance that the online merchants will desist from undesirables, unethical, opportunistic behaviour, such as unjust pricing, presenting wrong information, showcasing personal data and purchase activity without obtaining permission from the customer (Gefen, 2000).

\section{Theories on Technology Adoption Models}

The utilization of information technology and the user acceptance of such are fundamental factors with regard to the success achieved following enterprise adoption of the new technology. In an attempt to describe users' acceptance of information technology, a number of theories have been postulated by scholars, namely DTPB (Decomposed Theory of Planned Behaviour) (Taylor \& Todd, 1995),IDT (Innovation Diffusion Theory) (Moore \& Benbasat, 1991), TAM (Technology

Acceptance Model) (Davis, 1989), Extended Technology Acceptance Model (TAM2) (Venkatesh \& Davis, 2000), TPB (Theory of planned behaviour) (Ajzen, 1991), TRA (Fishbein et al., 1975) (Theory of Reasoned Action), and UTAUT (Unified Theory of Acceptance and Use of Technology) (Venkatesh, Morris, Davis, \& Davis, 2003). Amongst such theories, it is known that the most important and influencing IT-adoption theories are TAM, TAM2, TPB, TRA, and UTAUT (Min, Ji, \& Qu, 2008). 
The TAM (Davis, 1989) represents an adaptation of the TRA, tailored to users' acceptance of information systems. It helps explain determinants of technology acceptance and can explicate user behaviors across a broad range of computing technologies and populations; it also is parsimonious and theoretically justified (Davis, 1989). The major determinants are perceived usefulness and ease of use. Perceived usefulness significantly influences attitude formation (Davis, 1989; Taylor \& Todd, 1995; Venkatesh \& Davis, 2000).

In previous times, there has been wide-range acknowledgement and support of the TAM in terms of application, replication and validation, with the system regarded for its ability to estimate data utilization (Al-Shafi \& Weerakkody, 2008). Moreover, (Venkatesh \& Davis, 2000) state that TAM is regarded as being the most important and capable framework in terms of describing IS/IT adoption behaviours. The TAM model is extended further to include trust constructs.

\section{Technology Acceptance and Trust}

The extensively researched TAM (Davis et al., 1989) as well as the more recent UTAUT model (Venkatesh et al., 2003) are powerful theoretical frameworks for studying individuals' technology acceptance in general, and online shoppers' acceptance and buying behavior in particular. These models draw on the key constructs of perceived ease of use (PEOU) and perceived usefulness (PU) as indicators of technology acceptance or predictors of website usage behavior. PEOU is the degree to which one believes that using a website is free of effort, and PU is the belief that using a website increases shopping performance. The theoretical premise of the TAM is, in short, that PEOU affects PU, which in turn affects attitudes toward the system and ultimately usage intentions. Despite the advancements offered by the UTAUT, the present study relies on PEOU and PU as key constructs of technological website acceptance. This aligns with previous studies that integrate trust with technology acceptance constructs to explain online shopping behavior, although these studies use trust as a onedimensional construct.

Gefen et al. (2003) note that IS researchers studied technology acceptance and trust independently and that integrating the two perspectives "advances our understanding of these constructs and their linkages to behavior" (p. 51). Their initial theoretical discussion and empirical findings inspired a surge of subsequent studies. These studies show some inconsistent conceptualizations and results regarding the cause-and-effect relationships between technology acceptance constructs, trust and online shopping behavior. At times, trust and technology acceptance constructs are treated as independent (Van der Heijden, Verhagen and Creemers, 2003), or interlinked such that PEOU informs trust (Liao, Palvia and Lina, 2006), which then increases perceptions of website PU or website usability and ultimately behavior. Trust has also been either related or not related to perceived benefits or PU, which may then transfer effects of trust on behavior. Finally trust has been either directly linked to behavior or indirectly through other constructs. Apart from these inconsistencies, it is surprising that none of these studies differentiates the dimensions of trust.

\section{TAM model}

Rooted in the Theory of Reasoned Action (Ajzen and Fishbein, 1980), TAM is a framework for predicting and explaining consumers' adoption of IT (Davis, 1989). It is a framework for predicting and explaining consumers' adoption of information technology. It postulates that 
user acceptance of a new system is determined by the users' intention to use (IU) the system, which is influenced by the users' beliefs about the system's perceived usefulness (PU) and perceived ease of use (PEU).

\section{Proposed Model}

We propose the model of factors influencing consumer's intention to use the e-payment system. The proposed model is based on TAM to investigate customer's intention to use e-payment technology. Much research has been developed and modified based on the TAM model to get variables that correspond to the context of their research. In this proposed model, the decomposed trust construct (integrity, benevolence and ability) were added to the TAM model. Trust construct was added in this study because it is an important factor in the study of electronic payment systems and e-commerce.

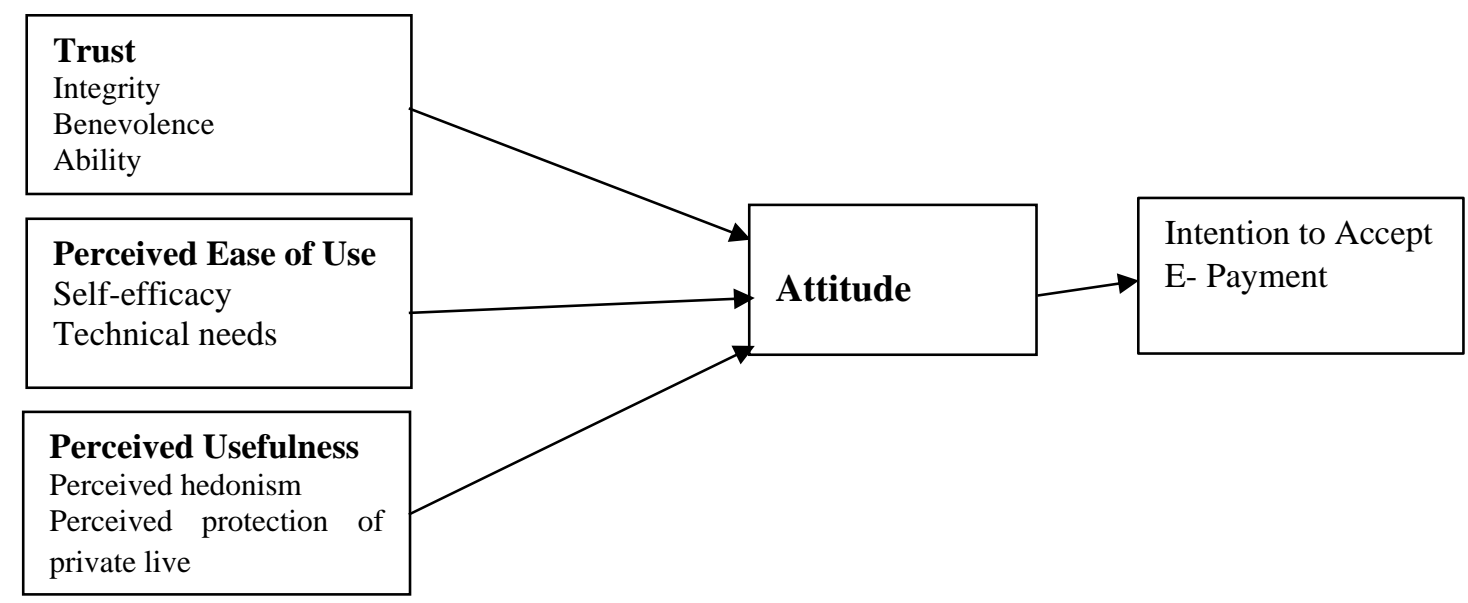

Figure 1: Extended TAM Model

\section{Trust Context}

The three dimensions of trust embrace utilitarian and affective elements to different degrees, which arguably is crucial for understanding how trust informs relational behaviors. Utilitarian elements reflect the consumer's perception that the object of trust will meet functional goals, such as the ability to perform as expected. Affective elements instead reflect perceptions that the object of trust is appropriate to meet relational goals, such as honesty, altruism or other pleasing characteristics of a good friend (Chaudhuri and Holbrook, 2001; Delgado-Ballester and Hernández-Espallardo, 2008). While integrity covers mainly affective or emotional evaluations (rather than utilitarian), the ability or competence dimension reflects utilitarian assessments of the provider. Finally, benevolence covers both utilitarian and affective evaluations (Hwang and Kim, 2007; McKnight et al., 2002). 


\section{Integrity Dimension}

Perceptions of ethical traits of firms improve consumer-company identification and loyalty intentions (Lichtenstein, Drumwright and Braig, 2004; Marin, Ruiz and Rubio, 2009), possibly due to consumers' affiliate motivations. Affiliate motivations stem from a relational goal or the innate human need to belong (Baumeister and Leary 1995; O'Connor and Rosenblood, 1996; Zimbardo and Formica, 1963). Such psychological attachment is not utilitarian and therefore unlikely to be related to the PU of the website. However, a company that earns a good reputation because consumers believe in its integrity may increase consumers' psychological attachment and relationship intentions (Thomson, McInnis and Park, 2005). Integrity is the trustor's perception that the trustee will adhere to a set of principles that the trustor finds acceptable. It is not just that they have principles, but the principles are ones that are acceptable to the trustor. For example if the trustee's values are to lie, cheat and steal every time they have a chance, this would not increase trust. More than anything else, integrity comes down to the question of will they do what they said they would do. Consumers want to know that if an organization promises something, will they follow through with that.

\section{Benevolence Dimension}

Sen, Bhattacharya and Korschun (2006) show that consumers who are aware of a company's benevolent efforts, such as social engagements, display higher levels of identification with the company. Higher levels of identification may enhance self-esteem and satisfy relational goals (Fournier, 1998; Sirgy, 1985). Hence, just as with integrity, we anticipate that beliefs about the firm's benevolence improve relationship intentions. In contrast to integrity, consumers' beliefs about the firm's benevolence may also satisfy functional goals. When consumers perceive a firm as benevolent, they will likely infer that the firm takes care to deliver expected performance levels.

Indeed, based on social exchange theory, Gefen et al. (2003) argue that greater levels of trust increase the perceived certainty about a company's expected behavior, in particular in relation to the PU of the e-payment platform. In this sense, benevolence is the subjective assessment that the firm provides ultimate benefits that the consumer searches for and that $s($ he) does not need to invest resources in monitoring if the expected benefits can be gained, making the website more useful (Gefen et al., 2003).

\section{Ability Dimension}

Finally, with the ability or competence dimension of trust, consumers assess the firm's capability to conduct transactions in a way that enhances efficiency and effectiveness. Ability, referred to as competence in some of the literature, is the group of skills, competencies and characteristics that enable a party to have influence within some specific domain. Ability is more than just their service with an individual, but extends to all aspects of how they conduct business. While the ability dimension includes domain level service to the consumer, it is not limited to that. Factors such as quality, innovativeness, prestige and others can influence the perception of ability. These aspects are purely utilitarian. For example, Komiak and Benbasat (2006) argue that a trustee may be highly competent without having integrity, which illustrates the crucial differences between these two dimensions of trust. When consumers perceive lower levels of competence, they must pay closer attention to all aspects of the transaction process, which increases their time and effort expenditures and reduces the PU of the platform. 


\section{Technology Acceptance Model}

The study framework examined in this research can be seen in Figure 1. In regard to the extended model, as per other works that have made changes to the framework (Al-maghrabi \& Dennis, 2009; Al-Shafi \& Weerakkody, 2008; Chong, 2012; Luarn \& Lin, 2005; Wei, Marthandan, Chong, Ooi, \& Arumugam, 2009). The constructs are supported through research conducted previously in the context of information system literature,

\section{Perceived Ease of Use (PEU) Context}

In accordance with the basic TAM, our extended model retains perceived ease of use from TAM as a direct determinant of attitude and an antecedent of intention to use (IU), both directly and indirectly via its impact on self-efficacy and technical needs (Davis, Bagozzi and Warshaw, 1989). A great deal of research has been carried out during recent years, with many providing much evidence to support the noteworthy impacts this element has on a consumer's intention to utilise a product or service, i.e. whether or not it impacts perceived usefulness (Khalifa \& Shen, 2008; S. Kim \& Garrison, 2009; Luarn \& Lin, 2005; Wei et al., 2009)

Self-efficacy: It addresses the user's perception of his or her ability to use a computer to accomplish a specific task (Venkatesh \& Davis, 2000). In general, when individuals are confident with their technology ability, they are more likely to accept new technologies. This linkage has been widely reported in the literature. For example, Tan and Teo (2000) and Lee and Kozar (2008) found that self-efficacy was significantly related to a user's intention of using Internet banking and anti-spyware software, respectively.

Technical needs: technology acceptance in general derives from needs. The greater the need for technologies, the more motivated the individuals are to accept the technologies. The underlying logic for this argument lies in expected utility theory, which posits that the decision makers are to maximize the utility the decision may cause. Technical needs present the utility potentials them technology acceptance may cause. In the literature, numerous studies reported that utility potentials have significant influences on attitude towards technology acceptance (Chen et al., 2010; Hsieh et al., 2008).

\section{Perceived Usefulness Context}

It has been stated that, in consideration to TAM, the perceived usefulness element is linked with various critical factors, namely effectiveness, performance and productivity (Davis, 1989). Perceived usefulness was defined as "the degree to which a person believes that using a particular system would enhance his or her job performance" (Davis, 1989). The literature has identified perceived usefulness as an important determinant of technology acceptance (Lee et al., 2003). For example, Lee, Kozar, and Larsen (2003) found that 74 studies reported a positive relationship between perceived usefulness and intention.

\section{Perceived hedonism (PH)}

One of the drawbacks of the TAM is that it does not take into account emotions as a predictor of perceived utility toward the act of using the new technology and usage intention. Indeed, consumer behavior theory provides evidence that utilitarian motives (economic and functional) are not sufficient to explain consumer behavior toward a product (Chitturi, Raghunathan and 
Mahajan, 2008). Hedonic motivation has been shown to influence technology acceptance and use very significantly, sometimes more than PU (Van der Heijden, 2004)

\section{Perceived Protection of Private Live (PPPL)}

Most commercial IT systems and associated databases (e.g. Google, Facebook, e- commerce such as Amazon.com) collect personal data associated with individual consumers in intimate ways that can be used to tailor personalized advertisements. This can be seen as intrusion and arouses concerns on privacy (Phelps, D'Souza and Nowak, 2001). The adoption of IT then depends heavily on the development of trust between the provider, the consumer and the IT systems. Perceived trust in new IT proves to be a direct antecedent of intention to use (IU) (Sirdeshmukh, Singh and Sabol, 2002; Dimitriadis and Kyrezis, 2010) and mediates the influence of PPPL on IU (Liu \& al., 2004).

\section{Attitude and Intention}

As explained by Rogers (1995), "Perceptions count ... the receivers' perceptions of attributes of an innovation, not the attributes as classified by experts or change agents, affect its rate of adoption" (p. X). Attitudes of potential adopters form the intention to the innovation so that they will decide to adopt or reject the innovation. IS researchers have suggested that intention models or behavioral decision theories from social psychology can provide a foundation for research on IT adoption by firms and IT usage by individuals (Harrison et al., 1997). Moreover, the theory of planned behavior (Ajzen, 1988; Ajzen, \& Madden, 1986) reveals that attitude toward behavior, subjective norm, and perceived behavior control together determine intentions, which, in turn, determine actions. The predictive power of attitudes to actual behavior is well supported by empirical studies (Mathieson, 1991). In this sense, the perception of decision makers is an effective predictor and explanation of the decision behavior. Many IS researchers have been inspired to study the adoption and usage of innovations by the consistency between attitudes and social behavior (Bhattacherjee \& Premkumar, 2004). For instance, Davis (1993) applied the attitude theory to study why users accept or reject information systems and how users' acceptance is affected by system design features. Harrison et al. (1997) applied the theory of planned behavior to explain and predict small business executives' decisions to adopt information technology. Moreover, Karahanna, Strub, and Chervany (1999) combined innovation diffusion and attitude theories in a theoretical framework to examine differences in pre-adoption and post-adoption beliefs and attitudes over IT innovation. The results of these studies confirmed the effectiveness of perceptions and attitudes in predicting and explaining acceptance or adoption behaviors of potential adopters.

\section{DISCUSSION AND CONCLUSION}

This paper is devoted to integrating and discussing the latest arguments on the technology acceptance model, and to provoke questions for further research. The key issues have been summarized into three major contexts: (1) trust and its dimensions, (2) The predictive use of the TAM model and (3) How the developed model relates to attitude and intention.

The literature on trust and e-payments fits very well into this framework, providing a useful tool to explore and further develop the trust literature. This framework is very useful for giving academics a way to explore, classify and develop consumer trust literature in a defined 
conceptual manner. This will also allow researchers to further look for gaps in the literature and propose further studies to explore those areas. This framework and model can also be used to understand the creation and sources of trust and give organizations a way to categorize trust based on its dimensions. The model enhances the importance of perceived competences and innovativeness in perceived ease of use. Feeling self-sufficient makes consumers more confident about their ability to use new technologies. Innovators, on their side, derive a positive stimulation from using a new product. Although the concept of trust is at the center of online marketing practice and research, we still know little about how the dimensions of trust relate to online consumers' assessments and ultimately their intentions to engage in a relationship with e-payment. Guided by theoretical developments from both IS and marketing literature, this research proposes a model that links three dimensions of trust (integrity, benevolence and competence) to two key constructs of technological acceptance in terms of PEOU and PU as a means to predict online consumers' relationship intentions.

\section{Theoretical Implications}

Drawing on literature from both the IS and the marketing fields, we developed theoretical rationales that explain the interactions between three dimensions of trust with key constructs of the technological acceptance model (PEOU, PU) in an attempt to ultimately explain relationship intentions. Findings therefore extend models integrating PEOU and PU with a dimensional conceptualization of trust. They clearly advocate that decomposing trust into its dimensions enables richer understanding of the driving forces of relationship intentions. The derived theoretical evidence suggests that integrity and benevolence relate directly to relationship intentions, while benevolence and competence relate directly to PU, which in turn informs relationship intentions.

\section{Managerial Implications}

The most significant managerial implication of this research is that lack of trust and privacy concerns remain the main obstacle to a widespread adoption of IT systems. By enhancing consumer trust marketers can enjoy long lasting differentiation and relevance in the mind of consumers. Marketing actions aimed at enhancing trust may affect relational behaviors through different routes, depending on whether these actions improve consumers' beliefs about the firm's integrity, benevolence or competence. Detailed insights into how the three dimensions of trust drive user behavior can help marketers to define key performance indicators along which they may fine-tune their marketing actions. We therefore recommend that online marketers identify how actions directed at improving trust in general do affect the dimensions of trust to improve their understanding of the perceptual and behavioral consequences of these actions. Flavian and Guinalíu (2006) argue that online vendors should highlight competencies for completing transactions, because the success of their business depends not only on integrity and benevolence, but also on the ability or competence to ensure that these intentions materialize. These aspects are functional in nature and may enhance relationships intentions when they are perceived as useful (PEOU).

\section{Limitations and Directions of Research}

This conceptual research has some limitations and leaves many questions unanswered. From a theoretical point of view, it only examines antecedents of technology acceptance. It would be interesting to examine the impact of the variables on the "real" use of an IT system or a digital 
service, with behavioral loyalty and usage indicators. Theory on technology adoption suggests several direct links between the model variables that have not been tested in this research (e.g. influence of perceived ease of use on perceived hedonism - Van der Heidjen, 2004; influence of perceived ease of use on trust intentions; Gefen, Karahanna and Straub, 2003). Further research could be conducted on empirical form.

\section{REFERENCES}

Abubakar S.A, \& Adebayo F.O., (2014). Analysis of Electronic Transactions Bill in Nigeria: Issues and Prospects. Mediterranean Journal of Social Sciences 5(2) DOI: 10.5901/mjss.2014.v5n2p215

Adeyelure S.T, Pretorius P., \& Kalema B.M, (2014). An E-Payment System in Nigeria: Success Militating Factors. International Journal of Advanced Computer Research (ISSN (print): 2249-7277 ISSN (online): 2277-7970) Volume-4 Number-1 Issue-14

Agarwal R. and Karahanna E. (2000), Time flies when you're having fun: cognitive absorption and beliefs about information technology usage, MIS Quarterly, 24, 4, 665694.

Ajzen I. and Fishbein, M. (1980), Understanding attitudes and predicting social behavior, Englewood Cliffs, NJ: Prentice-Hall

Ajzen, I. (1991). The theory of planned behavior. Organizational Behavior and Human Decision Processes, 50(2), 179-211.

Ajzen, I., \& Madden, T. J. (1986). Prediction of goal-directed behavior: Attitudes, intentions, and perceived behavioral control. Journal of Experimental Social Psychology, 22, 453474.

Akintola, K.G., Akinyede, R.O., Agbonifo, C.O. (2011). Appraising Nigeria readiness for ecommerce towards achieving vision 20:20. Int. J. Res. Rev. Appl. Sci. 9(2), 330-340

Al-maghrabi, T., \& Dennis, C. (2009). Driving online shopping: Spending and behavioral differences among women in Saudi Arabia. International Journal of Business Science and Applied Management, 5(1), 30-47.

Al-Shafi, S., \& Weerakkody, V. (2008). The use of wireless internet parks to facilitate adoption and diffusion of e government services: An empirical study in qatar.

Armesh, and Hamed. (2010), Electronic Payment and Its Implications. Interdisciplinary Journal of Contemporary Research in Business, 2(8), 246-255.

Baumeister, R. F.; Leary, M. R. (1995), « The Need to Belong: Desire for Interpersonal Attachments as a Fundamental Human Motivation », Psychological Bulletin, Vol. 117, $\mathrm{n}^{\circ} 3$, p. 497-529.

Bhattacherjee, A., \& Premkumar, G. (2004). Understanding changes in belief and attitude toward information technology usage: A theoretical model and longitudinal test. MIS Quarterly, 28(2), 229-254.

Chaudhuri, A.; Holbrook, M. B. (2001), « The Chain of Effects from Brand Trust and Brand Affect to Brand Performance: The Role of Brand Loyalty », Journal of Marketing, Vol. $65, \mathrm{n}^{\circ} 2$, p. 81-93.

Chen, D., Lin, Z., \& Lai, F. (2010). Crossing the chasm - understanding China's rural digital divide. Journal of Global Information Technology Management, 13(2), 4-36.

Chitturi R., Raghunathan R., and Mahajan V. (2008), Delight by design: the role of hedonic versus utilitarian benefits, Journal of Marketing, 72, 2, 48 - 63.

Chong, A. Y. L. (2012). Predicting m-commerce adoption determinants: A neural network approach. Expert Systems with Applications, 
Davis F. D., Bagozzi R. P., and Warshaw P. R. (1989), User acceptance of computer technology: a comparison of two theoretical models, Management Science, 35, 982 1003.

Davis F.D. (1989). Perceived usefulness, perceived ease of use, and user acceptance of information technology, MIS Quarterly, 13, 319-340.

Delgado-Ballester, E.; Hernández-Espallardo, M. (2008), « Effect of Brand Associations on Consumer Reactions to Unknown On-line Brands », International Journal of Electronic Commerce, Vol. 12, $\mathrm{n}^{\circ}$ 3, p. 81-113.

Dimitriadis S. and Kyrezis N. (2010), Linking trust to use intention for technology-enabled bank channels: the role of trusting intentions, Psychology and Marketing, 27, 8, 799820.

Flavián, C.; Guinalíu, M. (2006), « Consumer Trust, Perceived Security and Privacy Policy: Three Basic Elements of Loyalty to a Web site », Industrial Management \& Data Systems, Vol. 106, n ${ }^{\circ}$ 5, p. 601-620.

Fournier, S. (1998), « Consumers and their Brands: Developing Relationship Theory in Consumer Research », Journal of Consumer Research, Vol. 24, n 4, p. 343-373.

Gefen D., Karahanna E. and Straub, D. W. (2003), Trust and TAM in online shopping: an integrated model, MIS Quarterly, 27, 51-90.

Gefen, D. (2000). E-Commerce: the role of familiarity and trust, The International Journal of Management Science (IJMS), Omega, 28, pp. 725-737.

Gefen, D., and Straub, D. (2003). Managing user trust in B2C eServices, e-Service Journal, Indiana University Press, pp. 7-24.

Gholami.(2010), et al. Factors Affecting e-Payment Adoption in Nigeria. Journal of Electronic Commerce in Organizations, 8(4), 51-67.

Harrison, D. A., Mykytyn, P. P., \& Riemenschneider, C. K. (1997). Executive decisions about adoption of information technology in small business: Theory and empirical tests. Information Systems Research, 8(2), 171-195.

Hsieh, J. J. P.-A., Rai, A., \& Keil, M. (2008). Understanding digital inequality: comparing continued use of behavioral models of the socio-economically advantaged and disadvantaged. MIS Quarterly, 32(1), 97-126.

Huang, Echo., \& Cheng, Fa-Cheng.(2012) Online Security Cues and E-Payment Continuance Intention. International Journal of E Entrepreneurship and Innovation, 3(1), 42-58.

Hwang, Y.; Kim, D. J. (2007), « Customer Self-service Systems: The Effects of Perceived Web Quality with Service Contents on Enjoyment, Anxiety, and Etrust », Decision Support Systems, Vol. 43, n 3, p. 746-760.

Karahanna E. and Straub D.W. (1999), The psychological origins of perceived usefulness and ease-of-use, Information \& Management, 35, 4, 237-251.

Khalifa, M., \& Shen, K. N. (2008). Explaining the adoption of transactional B2C mobile commerce. Journal of Enterprise Information Management, 21(2), 110-124.

Kim, S., \& Garrison, G. (2009). Investigating mobile wireless technology adoption: An extension of the technology acceptance model. Information Systems Frontiers, 11(3), 323-333.

King W.R. and Le J. (2006), A meta-analysis of the technology acceptance model, Information \& Management, 43, 6, 740-755.

Komiak, S. Y. X.; Benbasat, I. (2006), « The Effects of Personalization and Familiarity on Trust and Adoption of Recommendation Agents », MIS Quarterly, Vol. 30, n 4, p. 941-960.

Laudon, Kenneth C., \& Traver, Carol G. E-Commerce 2011. 7th ed. Harlow: Pearson Education Limited. 2011. 
Lee M.K.O., Cheung C.M.K., Chen Z. (2005), Acceptance of internet-based learning medium: the role of extrinsic and intrinsic motivation, Information \& Management, 1095-1104.

Lee, Y., \& Kozar, K.A. (2008). An empirical investigation of anti-spyware software adoption: a multi-theoretical perspective. Information \& Management, 45(2), 109-119.

Lewis W, Agarwal L. and Sambamurthy V. (2003), Sources of influence on beliefs about information technology use: an empirical study of knowledge workers, MIS Quarterly, 27, 4, 657-678.

Liao, C.; Palvia, P.; Lina, H.-N. (2006), « The Roles of Habit and Web Site Quality in Ecommerce », International Journal of Information Management, Vol. 26, n 6, p. 469483.

Lichtenstein, D. R.; Drumwright, M. E.; Braig, B. M. (2004), « The Effect of Corporate Social Responsibility on Customer Donations to Corporate-supported Nonprofits », Journal of Marketing, Vol. 68, $\mathrm{n}^{\circ}$ 4, p. 16-32.

Liu C., Marchewka J.T., Lu J. and Yu C.S. (2004), Beyond concern: a privacy-trustbehavioral intention model of electronic commerce, Information \& Management, 42, 127-142.

Luarn, P., \& Lin, H. H. (2005). Toward an understanding of the behavioral intention to use mobile banking. Computers in Human Behavior, 21(6), 873-891.

Marin, L.; Ruiz, S.; Rubio, A. (2009), « The Role of Identity Salience in the Effects of Corporate Social Responsibility on Consumer Behavior », Journal of Business Ethics, Vol. 84, $\mathrm{n}^{\circ} 1$, p. 65-78.

Mathieson, K. (1991). Predicting user intentions: Comparing the technology acceptance model with the theory of planned behavior. Information Systems Research, 2(3), 173191.

McKnight, D. H., Choudhury, V., and Kacmar, C. J. (2002). Developing and validating trust measures for ecommerce: An integrative typology, Information Systems Research (ISR), 13(3), pp. 334-359.

McKnight, D. H., Kacmar, C. J., and Choudhury, V. (2004). Shifting Factors and the Ineffectiveness of Third Party Assurance Seals: A Two Stage Model of Initial Trust in a Web Business, Electronic Markets, 14(3), pp. 252-266.

Min, Q., Ji, S., \& Qu, G. (2008). Mobile commerce user acceptance study in china: A revised

UTAUT model. Tsinghua Science \& Technology, 13(3), 257-264.

Moore, G. C., \& Benbasat, I. (1991). Development of an instrument to measure the perceptions of adopting an information technology innovation. Information Systems Research, 2(3), 192- 222.

O’Connor, S. C.; Rosenblood, L. K. (1996), « Affiliation Motivation in Everyday Experience: A Theoretical Comparison », Journal of Personality and Social Psychology, Vol. 70, $\mathrm{n}^{\circ}$ 3, p. 513-522.

Okoro E. and Kigho P. (2013). The problems and prospects of E-transaction (The Nigerian Perspective): Journal of Research in International Business and Management (ISSN: 2251-0028) Vol. 3(1) pp. 10-16, January, 2013 Available online http://www.interesjournals.org/JRIBM

Osazevbaru Osahon \& Yomere, Gabriel O.(2015): BENEFITS AND CHALLENGES OF

NIGERIA'S CASH-LESS POLICY. Kuwait Chapter of Arabian Journal of Business and Management Review Vol. 4.

Phelps J.E., D’Souza G. \& Nowak G.J. (2001), Antecedents and consequences of consumer privacy concerns : an empirical investigation, Journal of Interactive Marketing, 15, 4, 2- 17. 
Quelch, J. A., and Klein, L. R. (1996). The Internet and international marketing, Sloan Management Review (SMR), 37(3), pp. 60-76.

Rogers E. M. (1983), Diffusion of innovations, New York: The Free Press.

Rogers, E. M. (1995). Diffusion of innovations (4th ed.). New York: Free Press.

Sen, S.; Bhattacharya, C. B.; Korschun, D. (2006), « The Role of Corporate Social Responsibility in Strengthening Multiple Stakeholder Relationships: A Field Experiment », Journal of the Academy of Marketing Science, Vol. 34, n 2, p. 158166.

Sirdeshmukh D., Singh J. and Sabol B. (2002), Consumer trust, value, and loyalty in relational exchanges, Journal of Marketing, 66, 1, 17-37.

Sirgy, M. J. (1985), « Using Self-Congruity and Ideal Congruity to Predict Purchase Motivation », Journal of Business Research, Vol. 13, n 3, p. 195-206.

Tan, M., \& Teo, T. S. H. (2000). Factors influencing the adoption of internet banking. Journal of the Association for Information Systems, 1(1), 1-42.

Taylor, S., \& Todd, P. A. (1995). Understanding information technology usage: A test of competing models. Information Systems Research, 6(2), 144-176.

Tella, Adeyinka. (2012). Determinants of E-Payment System Success: A User's Satisfaction Perspective. International Journal of EAdoption, 4(3), 15-38.

Teo, H. H., Wei, K. K., \& Benbasat, I. (2003). Predicting intention to adopt interorganizational linkages: An institutional perspective. MIS Quarterly, 27(1), 1-31.

Thomson, M.; McInnis, D. J.; Park, C. W. (2005), « The Ties that Bind: Measuring the Strength of Consumers' Emotional Attachments to Brands », Journal of Consumer Psychology, Vol. 15, $\mathrm{n}^{\circ}$ 1, p. 77-91.

Van der Heijden H. (2004), User Acceptance of Hedonic Information Systems, MIS Quarterly, 28, 4, 695-704.

Van der Heijden, H.; Verhagen, T.; Creemers, M. (2003), « Understanding Online Purchase Intentions: Contributions from Technology and Trust Perspectives », European Journal of Information Systems, Vol. 12, $\mathrm{n}^{\circ}$ 1, p. 41-48.

Venkatesh V. (1999), Creation of favorable user perceptions: exploring the role of intrinsic motivation, MIS Quarterly, 23, 239-260.

Venkatesh V. and Davis F.D. (2000), A theoretical extension of the technology acceptance model: four longitudinal field studies, Management Science, 46, 2, 186-204.

Venkatesh V. and Morris M.G. (2000), Why don't men ever stop to ask for direction? Gender, social influence, and their role in technology acceptance and usage behaviour, MIS Quarterly, 24 1, 115-139.

Venkatesh V., Morris M.G., Davis G.B. and Davis F.D. (2003), User Acceptance of Information Technology: Toward a Unified View, MIS Quarterly, 27, 3, 425-478.

Venkatesh, V., \& Brown, S. A. (2001). A longitudinal investigation of personal computers in homes: Adoption determinants and emerging challenges. MIS Quarterly, 25(1), 71-102.

Wei, T. T., Marthandan, G., Chong, A. Y. L., Ooi, K. B., \& Arumugam, S. (2009). What drives Malaysian m-commerce adoption? an empirical analysis. Industrial Management \& Data Systems, 109(3), 370-388.

Zimbardo, P.; Formica, R. (1963), « Emotional Comparison and Self-esteem as Determinants of Affiliation », Journal of Personality, Vol. 31, n 2, p. 142-162. 